\title{
Readiness to Communicate in a Digital World
}

\author{
Kathy Lynch \\ Faculty of IT, Monash University, Australia \\ kathy.lynch@infotech.monash.edu.au
}

\begin{abstract}
Communicating with friends, family, peers and colleagues has always underpinned work and social behaviour. However, the devices that act as conduits to this communication have changed over time, and differ across the globe. People in industralised corners of the world are more and more frequently using advances in information and communication technologies (ICTs) to assist both the senders and receivers to have more timely, synchronous and value-added communiqués. Well, that is what the promotional material is telling us.
\end{abstract}

The primary role of undergraduate education is to best prepare graduates for the workforce that they are being primed. To this end, educators need to be knowledgeable in what students already know, do, and their perceptions of what is required and is of value in assisting them to communicate with colleagues or peers.

This paper presents a study that aimed to identify directions for undergraduate IT curriculum in developing the information and communication technology (ICT) readiness of beginning IT (in particular Information Systems) professionals to work in a collaborative team.

Three hundred undergraduate Information Systems (IS) students were invited to participate in the study, one-hundred and sixty responded. The results indicate that there is a definitive relationship between frequency of use and the perceived value of an information and communication technology, and that the use of an ICT as a communication device in a social situation does not guarantee its use or even its perceived value as a communication device in a work situation: Visa versa is also true. Findings from the research could be used to influence IS curriculum developers in preparing undergraduate students' readiness for communicating (and collaborating) in the digital workforce of today.

Keywords: information and communication technologies, information systems, skill development, curriculum

\section{Background}

Material published as part of this publication, either on-line or in print, is copyrighted by the Informing Science Institute. Permission to make digital or paper copy of part or all of these works for personal or classroom use is granted without fee provided that the copies are not made or distributed for profit or commercial advantage AND that copies 1) bear this notice in full and 2) give the full citation on the first page. It is permissible to abstract these works so long as credit is given. To copy in all other cases or to republish or to post on a server or to redistribute to lists requires specific permission and payment of a fee. Contact Publisher@InformingScience.org to request redistribution permission.
Information technology workers of the $21^{\text {st }}$ century need to be conducive to new ways of working within the workplace; a workplace that revolves around communication, specifically, communication technologies. Not only is skill required in effectively using communication technologies becoming paramount, but the effective use of these communication technologies is also critical.

Work colleagues, social acquaintances, and family have a strong human need to 
maintain communications with each other even when in different temporal or spatial locations. Advancements in telecommunication technologies can facilitate and accommodate these new spaces through dissolving the boundaries or restrictions between them, according to Lipnack and Stamps (2000) "electronic media are dissolving the historic connection between physical place and social place” (p.16). These spaces are an integral part of today's workplace of today as it adopts a more collaborative format; and one that is less dependant on the location of its workers (Castells, 2001; Rice \& Mitchell-Ketzes, 2002; Wajcman, 2004). A common theme in the literature of today is expressed clearly by Wajcman (2004); "life is now mediated by technology" (p.1).

The industralised, 'third wave' (Toffler, 1980) IT worker is often part of a global team (Lynch, 2004); a team that has a strong reliance on technology. The use of technologies to assist in collaboration is not new; it has been reported by such researchers as Mankin, Cohen and Bikson (1996, p.6) who expressed the relationship as a synergy, however the reliance on ICTs to assist in the development of this synergy, is relatively recent. This synergy develops where the contribution of the two is greater than the sum of the parts in the development and improving the performance of the team. To develop this synergy, there needs to be an acceptance and adoption of the value of using communication technologies on collaborative projects. If a technology is to have a chance of improving a team's performance, individual team members need to be skilled in their use, and organizations need to address and manage the changes associate with adopting the new technologies and procedures.

ICTs are more than communication tools, they enable numerous interactions between team members that could otherwise not happen easily (Furst, Blackburn \& Rosen, 1999; Gould, 1998; Mankin, Cohen \& Bikson, 1996), and have been reported to enable the team to work "better, faster, cheaper and smarter" (Furst, Blackburn \& Rosen, 1999 p.249). Their use can compress space and time (Lurey \& Raisinghani, 2000), and through their creation of shared understandings, develop a shared trust (Schrage, 1990).

Castells (2001) argues that technology not only influences how we work, but the use of it is recursive; that is, technology is transformed by society, and society is transformed by technology therefore creating a new socio-technical interaction (pp.4-5). Bijker and Law's (1997) work is somewhat in agreement with Castells in that technologies have social implications in so much as teams using ICTs also have the ability to shape the technology to suit themselves and the organisation in which they work. This interaction can have implications that are advantageous (or not). The key is to manage and use the technology to its fullest advantage through interweaving it into society and work (Bijker \& Law, 1997; Casey, 1999; Castells, 2001). Technology should not constrain the development and creativity of team members, but rather enhance the work and allow the team members to develop in creativity and skill (Bijker \& Law, 1997 p.105).

The information technology profession is the focus of this study, and as in numerous other professions there is an increasing expectation that the new recruit will be part of a collaborative team to complete the tasks of the job. As an effective member of a collaborative team, the beginning IT professional needs to be proficient in the technologies that permit and encourage support between team members.

Information technology professionals therefore, need to be familiar, comfortable and confident with the technology that they use to complete their work in their, often global, workplace. Using the ICTs as an effective means to an end requires not only training in the technologies themselves, but the users require educating in the ubiquitous nature of the technologies and the decisions associated with their selection, use, appropriateness, modification and evaluation. Before an IT team can benefit from the use of ICTs for the greater team effort, individual team members need to be confident, efficient and value the worth of the ICT in enabling the collaboration. 


\section{The Research Study}

Given that ICTs are important for effective collaboration, collaborative teams underpin the way IT professionals work and will continue to work, and individuals are at the nucleus of a team, there is a need for the individual team members to be proficient in the use of the ICTs that underpin the effectiveness of the collaboration. To this end, a preliminary study was designed to investigate the perceived value or worth, and the frequency of use of popular ICTs by undergraduate information technology students in their everyday student life. The outcomes of this study can be used to direct curriculum enhancements that would better prepare students for the collaborative, ICT rich IT professional workforce.

\section{Method}

The study was conducted through the dissemination of a questionnaire to Information Systems undergraduate students enrolled at a large Australian university.

\section{Participants}

The participants selected for the study were from core units in each of the three year levels in the Bachelor of Information Systems. The students had been with their fellow students in these units for eleven weeks prior to the data collection. Each unit was selected on the premise that students had undergone some instruction on team work in previous weeks or previous years of their course, and that the students are expected to collaborate effectively in group work. During their development of team skills in these units the students are often exposed, though one cannot say with what regularity or level across classes in the one year or from one year to the next, to the use of ICTs for collaboration. Three hundred students were invited to participate in the study, onehundred and sixty questionnaires were returned. The responses, were from a mix of first (63), second (42) and third year (55) IS students.

\section{Data Instrument}

A questionnaire was devised to elicit responses regarding the respondents' perceptions as to the value of a particular ICT for work practices and for social interactions, plus their frequency of use of the selected ICTs. The use of ICTs in social situations was deemed an important aspect for investigation, so as to determine if there was any misalignment between the students' use of an ICT for one situation over another (for example, social rather than academic). The ICTs from which the respondents were asked to make comment on were ICTs that are used frequently by IS practitioners. It is acknowledged that there is a paradox between devices and services here, and that there is an unclear differentiation between 'The Device' and 'The Service'. This could create participate confusion in participant's responses to the questionnaire. However, as it is a presumption that the students are familiar with these terms, it did not seem to be a flaw in the instrument.

The ICTs selected for the study were:

- Voice and text messaging using a mobile phone

- Email

- Synchronous chat (e.g. MSN,ICQ) using the Internet

- Video/audio chat using the Internet

- Asynchronous discussion areas using the Internet. 
The questionnaire (Table 1) captured data regarding the respondents' frequency of use of the selected ICTs. A six point Likert-type scale was presented for the respondent to select the most appropriate answer, these were then coded as 5 = "Lots-every day use", $4=$ "Frequently-a few times a week", 3 = "once a week", 2 = "a few times a month", 1 = "rarely", 0 = "never", and a null data entry was made if the question was unanswered.

To establish the perceived value of an ICT in an academic and social context, the questionnaire also included questions using a five point Likert-type scale was presented for the respondent to select the most appropriate answer, these were then coded as 5 = "highly valued", 4 = "moderately valued", 3 = "of little value", 2 = "unsure", 1 = "no value", and a null data entry was made if the question was unanswered.

Table 1. Questionnaire

\begin{tabular}{|c|c|c|c|c|c|c|}
\hline $\begin{array}{l}\text { Tick the technologies that you feel you are } \\
\text { comfortable in using (you can select more } \\
\text { than one). AND tick your frequency of use }\end{array}$ & $\begin{array}{l}\text { Lots } \\
\text { (every } \\
\text { day) }[5]\end{array}$ & $\begin{array}{c}\text { Frequent } \\
\text { (a few times } \\
\text { every week) } \\
\quad[4]\end{array}$ & $\begin{array}{l}\text { Maybe } \\
\text { once a } \\
\text { week [3] }\end{array}$ & $\begin{array}{c}\text { A few } \\
\text { times a } \\
\text { month }[2]\end{array}$ & $\begin{array}{c}\text { Rarely } \\
\text { [1] }\end{array}$ & $\begin{array}{c}\text { Never } \\
{[0]}\end{array}$ \\
\hline \multicolumn{7}{|l|}{ D Voice and text messaging (Mobile Phone) } \\
\hline \multicolumn{7}{|l|}{$\square$ Email } \\
\hline \multicolumn{7}{|l|}{ Internet synchronous text chat } \\
\hline \multicolumn{7}{|l|}{ Internet video or audio chat } \\
\hline \multicolumn{7}{|l|}{ Internet asynchronous chat } \\
\hline \multicolumn{7}{|c|}{$\begin{array}{l}\text { 2B. Rate your perception of their value to team members in working on group projects. Where } 5 \text { is "highly } \\
\text { valued", } 4 \text { is "moderately valued", } 3 \text { is "unsure", } 2 \text { is "little value" and } 1 \text { is of "no value at all". } \\
\text { 3A. Tick the technologies that you use for entertainment or social contact? } \\
\text { 3B. Rate your perception of their value to the participants engaged in the entertainment or social contact. } \\
\text { Where } 5 \text { is "highly valued", } 4 \text { is "moderately valued", } 3 \text { is "unsure", } 2 \text { is "little value" and } 1 \text { is of "no } \\
\text { value at all" }\end{array}$} \\
\hline $\begin{array}{l}\text { 2A. Tick the technologies that you have used } \\
\text { use when working on group projects? }\end{array}$ & $\begin{array}{l}\text { 2B. } \\
\text { Rating }\end{array}$ & $\begin{array}{l}\text { 3A. Tick } \\
\text { use for } \mathbf{e} \\
\text { contact? }\end{array}$ & $\begin{array}{l}\text { the techno } \\
\text { itertainm }\end{array}$ & $\begin{array}{l}\text { gies that you } \\
\text { t or social }\end{array}$ & $\begin{array}{l}\text { 3B. } \\
\text { Ratin }\end{array}$ & \\
\hline$\square$ Mobile voice/text & $5,4,3,2,1$ & $\square$ Mob & e voice/tes & & $5,4,3$ & \\
\hline$\square$ Email & $5,4,3,2,1$ & $\square \mathrm{Ema}$ & & & $5,4,3$ & \\
\hline Internet synchronous text chat & $5,4,3,2,1$ & $\square$ Inter & et synchro & ous text chat & $5,4,3$ & \\
\hline Internet video or audio chat & $5,4,3,2,1$ & Inter & et video c & audio chat & 5,4 & \\
\hline Internet asynchronous chat & $5,4,3,2,1$ & $\square$ Inter & et asynchr & gous chat & $5,4,3$ & \\
\hline
\end{tabular}




\section{Data Analysis}

To allow for comparison between the frequency and the value data, the frequency scores of 5 to 0 were transposed in to scores in the range of 5 to 1 to match the range for the value data (5 to 1 ). These transpositions are shown in Table 2.

\begin{tabular}{c|l}
\hline \multicolumn{2}{c}{ Table 2 . Re-coding of frequency of use } \\
\hline Old & New (frequency) \\
\hline 5 & 5.0 (lots, every day) \\
\hline 4 & 4.2 (few times a week) \\
\hline 3 & 3.4 (maybe once a week) \\
\hline 2 & 2.6 (a few times a month) \\
\hline 1 & 1.8 (rarely) \\
\hline 0 & 1.0 (never) \\
\hline Null & No response \\
\hline
\end{tabular}

It is acknowledged that as students progress through the years of their degree, they develop and master the skills and techniques that they are exposed to: Therefore one should expect $3^{\text {rd }}$ year students to be more knowledgeable and proficient in the use of ICTs than first year students, therefore the data presented has been displayed according to year levels so as to see if there is a transition from year to year.

Though there was an area in the questionnaire for the participants to add open comment, this option was not taken up by enough participants to make a rigorous analysis of the data, and therefore have not been included in the paper.

\section{Results and Findings: Frequency of Use}

The questionnaire asked participants to select from a list of phrases, the one that best described their use of the selected ICT in any context. To determine if there were any trends in the frequency of use of a particular technology, the mean score to two significant figures was calculated for the frequency of use for each ICT. The mean scores are presented in Figure 1.

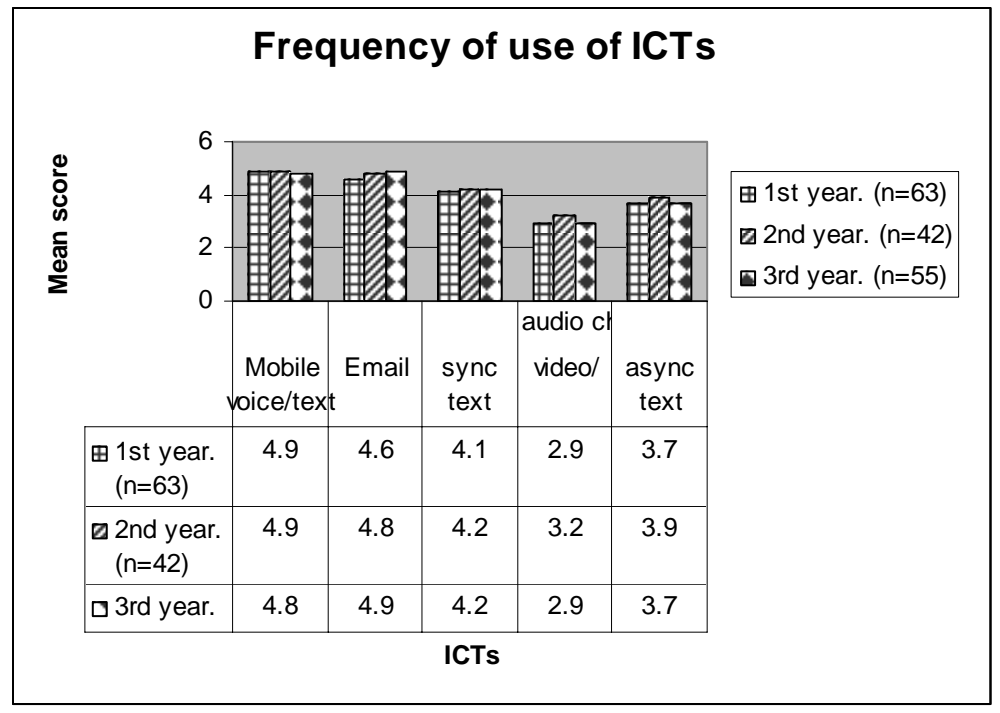

Figure 1. Frequency of use of ICTs

Voice and text using a mobile phone is typically the most frequently used ICT, and are used everyday across the three year levels of participants. The use of email is the next most frequently used ICT from the given list, with $2^{\text {nd }}$ and $3^{\text {rd }}$ year students frequency of use just a little above that of $1^{\text {st }}$ year students surveyed. Of the remaining ICTs listed all but synchronous video/audio chat are also used everyday by the survey respondents. The lower level of use for synchronous Internet video/audio chat could be due to a number of reasons, such as, the non-availability of hardware to interact with users, and the relative small number of users of the technology. The use of mobile 
phones and email are two common technologies that have become ubiquitous in many western societies, in particular university settings. It is interesting to note that the number of responses relating to the frequency of use of synchronous video/audio chat and asynchronous chat were lower than for the other ICTs (74\% and 71\% respectively). This indicates less skill and or knowledge in the technologies, and it seems, therefore, a lower level of use.

Overall, there is little variation in typical responses for the top three ranked ICTs; mobile voice and text, email and synchronous Internet chat, therefore it is educationally difficult to differentiate between them. Nevertheless, the analysis was done to separate the ICTs, but as the results indicate, there is no claim that statistically they mean anything. Furthermore, and more importantly, educationally and in terms of the consequences of the research, there is very little significant difference in the ranking.

Third year students appear to use email and synchronous chat more frequently than respondents from the other two years. This could be due to the type of communications (such as long messages, attaching files, scheduled meeting times), their familiarity with the technology, no cost to send or receive messages, and the readily availability of the technology. The technologies associated with synchronous Internet text chat (for example MSN, ICQ) are widespread, popular, cheap, and have reached many households and workplaces over the last three years. Furthermore, mobile phones are 'wearable' and often easier to use than email as they do not require plugging in or shared access. However, the sending and receiving of messages costs more than email, and this could possibly be of a greater consideration to students who have become more independent as they progress through their course.

It could be argued that the use of less popular technologies, such as synchronous Internet video and audio chat is not yet common or accepted as the technologies associated with the more obtainable synchronous Internet text chat. However, second year respondents use these technologies more frequently than respondents from the other two years. This could be due to first year students being overwhelmed with the ICTs before them and having to become accustomed to much in a short period of time, and third students having explored numerous technologies, and are now more likely to use their preferred methods of communications - that is, email, mobile voice/text and synchronous Internet chat.

\section{Results and Findings: Perceived Value}

To investigate if there were any trends in the respondents' perceived value of the listed ICTs when working in groups for academic purpose and for social purposes, the questionnaire asked respondents to select from a list of terms, the one that best described their perceived value of the listed technology. The mean score to two significant figures was calculated for the perceived value of each ICT in an academic and social setting, and are presented in Error! Reference source not found.

The perceived academic value of email and mobile voice/text is typically high with little variance. The most typical response for the perceived value of synchronous Internet video/audio chat for academic group work varies between no value to little value. This, together with the low response rate for this particular question indicates that the respondents may not understand the technology or may not have had the opportunity to use the technology in an academic setting, and therefore they had trouble perceiving its value.

The ICTs that are typically perceived as most highly valued are mobile voice/text, email and synchronous text chat. The use of mobile voice/text services using a mobile phone are unanimously perceived as of high valued for social communications. It is not surprising that email and synchronous Internet text chat are both valued and ranked highly, as they use the Internet as their 
Lynch

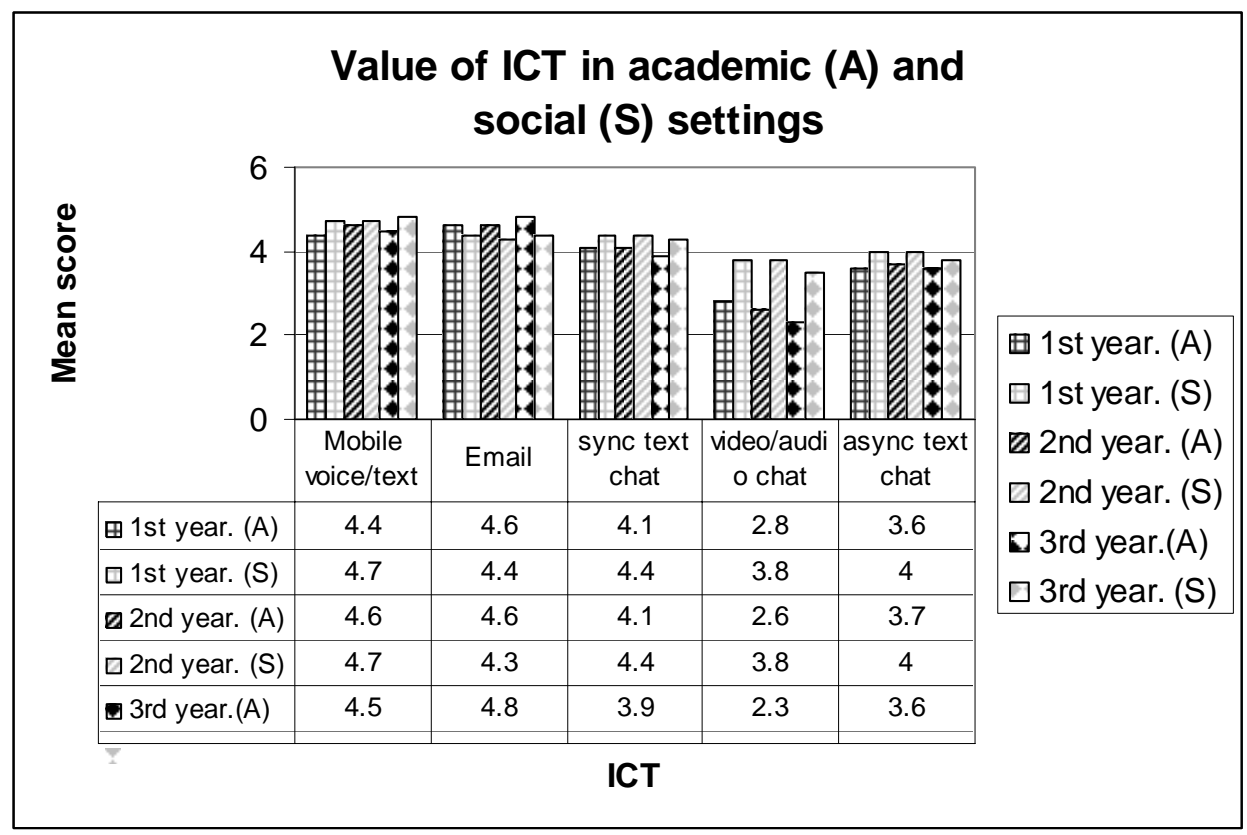

Figure 2. Perceived value in academic and social settings

underpinning technology, are free, and are in generally popular no matter the location of the sender or receiver.

Once again, as in the frequency of use, the number of responses relating to the perceived value of synchronous video/audio chat and asynchronous chat were lower than for the other ICTs, with the average of responses for academic and social, 40\% and 55\% respectively. This indicates a significant lack of skill and or knowledge in the technologies, and it seems, therefore, leading to a low level of not only their use but participants' perceived value of synchronous video/audio chat in particular for academic work. This seems to be in direct contract to what has been found in the literature which argues that we are social beings and require face-to-face contact (Becker \& Sims, 2001. p5).

\section{Results and Findings: Frequency of Use / Perceived Value}

The questionnaire allowed for an exploration of correlations between the frequency of use of an ICT and its perceived value in academic or social settings. The ICTs explored were based on the results of frequency and perceived value as presented above, in so far as those that displayed a positive response where used to explore the possibility of correlations. The ICTs that were investigated further were voice and text from a mobile phone, email and synchronous Internet text chat. It is not surprising that these three ICTs produced a response rate of 65 per cent or above in all questions. The level of statistical significance also influenced the selection for analysis of the findings and therefore a Chi-square test was conducted on only the relationships that showed a level of significance at 0.05 or 0.01 were explored.

Chi-square (or Pearson's chi-square) is a non-parametric technique used to explore relationships or the "goodness of fit" (Cramer \& Howitt, 2004) between two categorical variables. Neuman (2000 p.340) states that cross tabulations between at least two variables using chi-square is a valid inferential statistical measure. When interpreting the chi-square results, one needs to look at the percentage of cells that violate the expected value (less than 5). If this value is greater that zero per cent, then the assumptions of the chi-square test are violated, and therefore confidence is reduced in the chi distribution. As a result the test can only be interpreted as an indication rather 
than statistically conclusive (Neuman, 2000). After conducting the chi-square technique on the listed variables, it was found that all results had some cells that had an expected count greater than five, therefore the results can only be used as an indication rather than statistically conclusive. Regardless, the results do have some educational relevance and therefore add to fulfilling the research aims.

The following relationships met the criteria in both an academic and social setting:

- frequency of use * value of mobile voice/text using a mobile phone,

- $\quad$ frequency of use * value of email,

- $\quad$ frequency of use * value of synchronous Internet text chat.
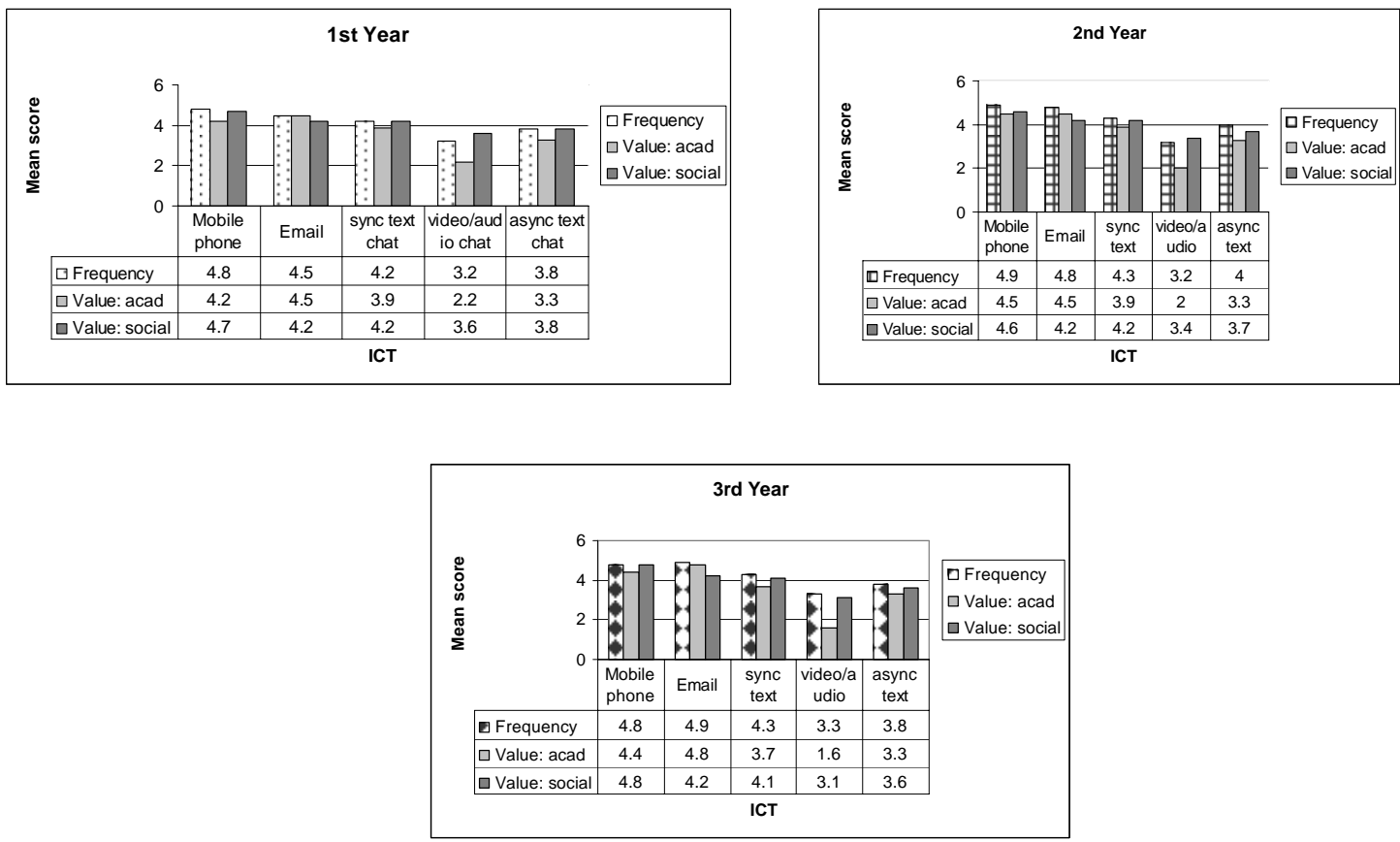

Figure 3. Frequency and perceived value of ICTs

To further explore the relationship between the above variables, mean scores were calculated on each of the above variables for each year level. These results are presented in Error! Reference source not found..

Of a possible maximum mean of 5.0, the use of mobile phones, email and synchronous Internet text chat stand out as the most prominent technologies and of the greatest value in both academic and social settings. Asynchronous Internet text chat, though not used as frequently as email, mobile phones or synchronous Internet text chat, appears to be perceived as valuable in both contexts. It can be seen that often an ICT has a higher social value than academic value, and that there is a high correlation of transfer of value in the ICTs for academic and social context apart from when using video/audio chat. The respondents indicted that they use video/audio chat frequently and value it in a social content, but rated its value as low in an academic context. It could be argued that this indicates that the students have not yet learnt the flexibility of the technology; an area that should be addressed during their undergraduate studies so as to better prepare them for the workforce. 
The results indicate clearly that an ICT that is used frequently is also perceived as valuable to the setting in which it is used. There is little differentiation between the results for voice/text using a mobile phone, email and synchronous Internet text chat.

Typically the respondents who use mobile phones for voice and text messaging, and email a number of times every day, perceive their value as high in assisting with academic and social interactions. What is surprising is the relatively high percentage of respondents who frequently use and value synchronous Internet text chat in academic settings. This leads the researcher to believe that students are familiar with some of the newer ICTs, and value and use the technologies for group work.

\section{Conclusion}

The trend that is evident in the results is that the less frequently used ICTs are perceived to be lower in value in either academic or social settings, with video/audio chat ranking last and mobile voice/text ranking first. What is interesting to note is the overall commonality in ranking between the three years; that is mobile voice/text, email, synchronous text chat, asynchronous text chat then video chat. I also it appears that third year students do not use nor value (overall) the selected ICTs anymore than the first year students. This could be interpreted as over the duration of their program, the students do not see any additional value nor do they increase their frequency in use of the selected ICTs. Educationally this is of concern, as the ubiquitous use of ICTs is fundamental to the skills and attributes required of beginning IS graduates to be productive members of the IS profession, and effective members of collaborative IS teams (Lynch, 2004). This finding further supports the need to educate these students in the use and value of ICTs in their IT-rich lives.

Emerging from the results there is evidence that the students see and use the technologies according to two categories, with one technology bridging the two:

Category 1 (high use and high value) - voice/text chat using mobile phones, and email, bridging synchronous Internet text chat,

Category 2 (low use and low value) - synchronous Internet video/audio chat, asynchronous Internet text chat.

The ICTs that fall into the first category are used frequently and are highly valued in both academic and social group settings. The respondents overwhelmingly perceived that the social value of synchronous Internet text chat is just as good as using a mobile phone for voice/text chat, and the value of email for academic group work is equal to the value of using a mobile phone for voice/text chat. These three ICTs are accepted as valuable communication technologies regardless of context.

The second group of ICTs is more diversified in the respondents' frequency of using them and their perceived value. The technologies underpinning synchronous Internet video/audio chat and asynchronous Internet text chat are still relatively new and their use is not yet a part of everyday life. However, with the advancement in technology, and in particular, mobile technologies, there is a likelihood that these ICTs will become aligned in use and value with the ICTs listed in group one.

Together with the advancement of multimedia technology, its convergence with telephony and advancements in Internet video and audio chat, there is a probability that the merger of these technologies will supersede any single technology on its own. This will be further intensified through the lower costs of the devices and services that accommodate the need to faster, better, smarter ways of collaborating on projects. 
However, without a concerted effort in the development and implementation of curriculum, and in particular IS curriculum, that has a focus on developing students' ubiquitous use of ICTs in their work and social contexts, in general they will not develop the required skills and attributes informally (or through osmosis). Further research needs to be conducted to confirm the results of the study, and to extend it to include a study of both curriculum and IT students from more diverse and global locations.

\section{Acknowledgements}

The author would like to thank Professor Dick Gunstone and Associate Professor Julie Fisher (Monash University) for their valued assistance during this project.

\section{References}

Bijker, W. \& Law, J. (1997). Shaping technology/building society. Cambridge, Massachusetts: MIT Press.

Casey, C. (1999). The changing contexts of work. In D. B. J. Garrick, Understanding learning at work. Routledge, London

Castells, M. (2001). The Internet galaxy: Reflections on the Internet, business, and society. Norfolk: Oxford University Press.

Cramer, D. \& Howitt, D. (2004). The SAGE dictionary of statistics. London: SAGE Publications.

Furst, S., Blackburn, R. \& Rosen, B. (1999). Virtual team effectiveness: A proposed research agenda. Information Systems Journal, Special issue on virtual teamworking, 9 (4), 249-270.

Gould, D. (1998). Virtual organization: Virtual teams, Retrieved May 2001 from http://www.seanet.com/ daveg/vrteams.htm

Lipnack, J. \& Stamps, J. (2000). Virtual teams: People working across boundaries with technology. New York: John Wiley \& Sons.

Lurey, S. \& Raisinghani, M. (2000). An empirical study of best practices in virtual teams, Retrieved May 2003 from http://citm.utdallas.edu/Publications/Whitepapers/BestPractices.html

Lynch, K. (2004), Collaborative work skills for beginning IS professionals. In Issues in Informing Science and Information Technology, 1, 417-429. Available at http://articles.iisit.org/066lynch.pdf

Mankin, D., Cohen, S. \& Bikson, T. (1996). Teams and technology: Fulfilling the promise of the new organisation. Boston: Harvard Business School Press.

Neuman, W. L. (2000). Social research methods: Qualitative and quantitative approaches. Boston: Allyn \& Bacon.

Rice, J. \& Mitchell-Ketzes, S. (2002). Success stories from new workplace. Retrieved May 2003 from http://www.facilitiesnet.com/bom/Aug02/Aug02facility.shtml

Schrage, M. (1990). Shared minds: The new technologies of collaboration. New York; Random House.

Toffler, A. (1980) The third wave: A classic study of tomorrow. Bantam Books

Wajcman, J. (2004). Technofeminism. Cambridge, UK: Polity Press.

\section{Biography}

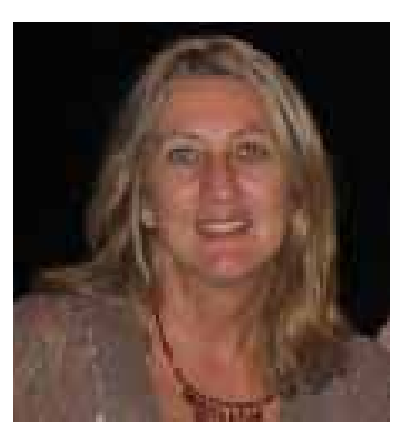

Dr Kathy Lynch is a senior lecturer in the Faculty of Information Technology at Monash University,Australia. Her current research interests encompass collaborative work, enabling and emerging technologies, HCI, usability and IS/ICT education. She has a Doctor of Philosophy (Education), and numerous other qualifications in the both the disciplines of IT and Education.

(http://www.sims.monash.edu.au/staff/klynch/ ) 